\title{
Las recurrencias de herpes genital tienden a disminuir con el tiempo en la mayoria de los pacientes
}

Clinical Reactivation of Genital Herpes Simplex Virus Infection Decreases in Frequency over Time Benedetti J, Zeh J, Corey L. Ann Intern Med 1999; 131: 14-20.

\section{Objetivo}

Determinar la evolución de las recurrencias de Herpes Genital a lo largo del tiempo.

\section{Diseño}

Estudio observacional de cohortes*.

\section{Lugar}

Centro de investigación virológica, Universidad de Washington, EE.UU.

\section{Pacientes}

Se incluyeron 664 pacientes ( $42 \%$ hombres). Se los clasificó al inicio del estudio en infecciones primarias o recurrentes de acuerdo a la ausencia o presencia de anticuerpos por Western Blot (306 pacientes tuvieron infecciones primarias y 358 fueron recurrencias). La mediana de seguimiento fue 36 meses (entre 14 y 223).

\section{Medición de Resultados Principales}

Se instruyó a los pacientes a concurrir ante cualquier síntoma genital y a reconocer las lesiones herpéticas; asimismo debían presentarse trimestralmente (semestral si distinguían bien la patología) para un control general.

\section{Resultados Principales}

Se analizaron más de 12.000 recurrencias. En el primer año, la tasa mediana* de recurrencia fue de 1 para las infecciones primarias de Herpes tipo 1 y de 5 pare el Herpes tipo 2; las recurrencias disminuyeron significativamente el segundo año. Para los pacientes con Herpes 2 recurrente las tasas fueron altas en los dos primeros años (Ver Tabla 1). Los pacientes con Herpes tipo 2 que fueron seguidos por más de 5 años tuvieron en promedio 2 recurrencias menos entre el quinto y el primer año, pero un 25\% tuvo al menos una recurrencia más al quinto año, mostrando cierta variabilidad en la evolución. La disminución de las recurrencias se observó tanto en pacientes que habían recibido tratamiento supresor como los que no lo hicieron.

Tabla 1. Tasas de recurrencia en los primeros 2 años

\begin{tabular}{lc|c|c|c|c}
\hline Variable & $\begin{array}{c}\text { Inf. Primaria } \\
\text { HS 1 }\end{array}$ & $\begin{array}{c}\text { Inf. Primaria Inf. No Primaria HS 2@ } \\
\text { HS 2 } \\
\text { inicial }\end{array}$ & $\begin{array}{c}\text { Inf. Recurrente } \\
\text { HS 2 }\end{array}$ & Total \\
\hline $\begin{array}{l}\text { Pacientes con datos } \\
\text { disponibles en } \\
\text { primeros 2 años }\end{array}$ & 59 & 191 & 39 & 316 & 605 \\
\hline $\begin{array}{l}\text { Tasa de recurrencia } \\
\text { (mediana*) 1er año }\end{array}$ & 1 & 5 & 5 & 6 & 5 \\
\hline $\begin{array}{l}\text { Tasa de recurrencia } \\
\text { (mediana*) 2do año }\end{array}$ & 0 & 4 & 4 & 6 & 5 \\
\hline $\begin{array}{l}\text { Diferencia media } \\
\text { Valor p }\end{array}$ & 0 & 0,3 & 1 & 0,2 & 0,3 \\
\hline
\end{tabular}

@Inf primaria por HS 2 pero con anticuerpos para tipo $1 ; \mathrm{HS}=$ Herpes simple

Tabla 2. Evolución de los pacientes seguidos por 3 o más años

\begin{tabular}{lcccc}
\hline Grupo & Pacientes & $\begin{array}{c}\text { Tasa de recurrencia } \\
\text { anual 1er año }\end{array}$ & $\begin{array}{c}\text { Disminución por año } \\
\text { en Tasa de recurrencia } \\
\text { anual ( IC 95\%) }\end{array}$ & Valor p \\
\hline Inf. Primaria HS 1 & 38 & 1,7 & $0,5(0,1-0,8)$ & 0,004 \\
\hline Inf Primaria HS 2 & 155 & 6,3 & $0,8(0,4-1,2)$ & 0,001 \\
\hline Inf recurrente HS 2 & 219 & 8,5 & $0,7(0,3-1)$ & 0,001 \\
\hline
\end{tabular}

\section{Conclusiones}

El $75 \%$ de los pacientes tuvo un descenso clínicamente significativo de recurrencias a los cinco años de seguimiento; esto permite a los médicos reevaluar la necesidad de tratamiento supresor diario.

\section{COMENTARIO}

El Herpes Genital es una de las enfermedades de transmisión sexual más frecuentes en el mundo. De curso crónico y recurrente en inmunocompetentes, puede llegar a ser mortal en neonatos e inmunocomprometidos.

Según datos recientes de un Programa Nacional de Salud en EE.UU., la seroprevalencia del Herpes Simple tipo 2 alcanza el $22 \%$ en mayores de 12 años de ambos sexos (45 millones de personas), con un aumento del $30 \%$ con respecto a una década atrás, sobre todo en adolescentes ${ }^{1}$. Lo más preocupante es que un $90 \%$ no reconoce un antecedente de Herpes Genital. El tremendo impacto que produce conocer estos números y su continuo aumento, obligan a los médicos a informar sobre esta enfermedad, como prevenirla (el preservativo es insuficiente debido a las múltiples localizaciones del virus), y que las lesiones activas facilitan la transmisión del HIV.

La importancia de este trabajo radica en que es el primero en analizar el curso clínico de la enfermedad, sin tener en cuenta si recibieron tra- tamiento supresor, este dato es interesante ya que no estaba claro si las recurrencias disminuían por el tratamiento supresor o si esto era parte de la historia natural de la enfermedad.

La muestra seleccionada representa pacientes con casos severos que debe ser tenido en cuenta a la hora de generalizar los resultados. Como todo estudio de seguimiento, las perdidas significan el principal problema, en este sólo el $42 \%$ fue seguido por mas de 3 años y un $18 \%$ mas de 6 años, este es un dato muy fuerte que impide conocer con certeza la evolución a largo plazo.

Como conclusión, los hallazgos de este estudio no permiten tomar una conducta definitiva. Tal vez, con la existencia de mayor evidencia, se pueda pensar que aquellos pacientes que reciben tratamiento supresor por sus frecuentes recurrencias, puedan suspender este tratamiento luego de 3-5 años de seguimiento y controlar periódicamente su evolución.

*Ver glosario

\section{Dr. Cristián Dellepiane}

Unidad de Medicina Familiar y Preventiva. Hospital Italiano de Buenos Aires.

\section{Referencias}

1. Herpes Simplex Virus Type 2 In The United States, 1976 To 1994. Fleming D, Mc Quillan G, Johnson Ry col. NEJM. 1997 0ctubre 16; 337: 1105-11. 